\title{
Traces of Vlach Migrations in the Toponymy of the Polish Podtatrze Region
}

\author{
Ślady migracji wołoskich w toponimii polskiego Podtatrza
}

\section{STRESZCZENIE}

W gwarach podhalańskich obecne są elementy leksykalne, których pochodzenie wiąże się z migracją pasterzy wołoskich na terenach polskiego Podtatrza. Występują również w toponomastyce. Utworzone zostały najczęściej na podstawie rumuńskich gwarowych apelatywów, np. oronimy Grapa, Magura, a także nazwy wsi lokowanych na prawie wołoskim lub zamieszkanych przez osadników wołoskich, np. Łapsze, Poronin. Na polskim Podtatrzu, które obejmuje Spisz, Podhale i Orawę, wśród 93 miejscowości jedynie w sześciu przypadkach, w stanie obecnych badań, można wskazać etymologię rumuńską (wołoską). Nie jest to jednak ostateczny stan badań i wymagają one kontynuacji.

Słowa kluczowe: Wołosi, Podtatrze, toponimia Podhala, osadnictwo wołoskie

When searching for new pastures for their herds, the Vlach shepherds used to roam mountain trails, venturing into ever more remote parts of the North and West Carpathians. The Vlach colonization of the northern part of this mountain range most probably began in the $13^{\text {th }}$ century, moving west up to the rocky ridges of the Tatras, the Beskid Śląski, and East Moravia. What the Vlach shepherds brought with them was the pastoral culture - unfamiliar to the locals. The sheep and goat grazing trails leading along mountain pastures and ridges started to gain a new economic value, as a result of which many formerly nameless mountainous areas, valleys, and rivers were named in the language of the new settlers - I assume that the Vlach shepherds, who managed to reach the northern regions of the Carpathians, spoke one of the dialectal variants of the Romanian language. According to toponym researchers, the first elements to be named in the new territories included rivers and other distinctive 
water bodies, which then gave rise to the names of villages and towns, e.g. the village of Rzepiedź in the Sanok District was established by the Rzepedka stream (see: repede meaning fast in Romanian). Another factor that played some role in the onomastics of Polish villages was the Vlach law, on which villages started to be established as early as the $14^{\text {th }}$ century on the eastern frontiers of medieval Poland, and from the late $16^{\text {th }}$ century in the Podtatrze region - however, it is important not to overestimate the influence of this factor on geographical names of the Podtatrze region ${ }^{1}$. The last elements to be named were individual mountain ranges and summits. Their names alluded to the lands or objects located at mountain tops or on slopes like farmlands, forests, and pastures, as well as those located in the immediate vicinity of the settlers ${ }^{2}$. It must be noted, however, that people at that time did not give names to summits. Instead, they rather named individual mountains and mountain ridges, which often constituted a natural division between the territories of neighboring farmlands, villages, and countries. The summit names as we know them today were usually coined by scientists, including cartographers and geographers, and then by tourists (relatively late). The Tatra topographical terminology became well-established in the common nomenclature after 1900, mainly due to different publications such as the Tatra Mountain guides and magazines devoted to the Tatras (e.g. Taternik), and thanks to the initiatives of the Polish Tatra Society (PTT) as well.

When comparing the terrain of the Tatras and Podtatrze region with the location of toponyms and other points which could be linguistically (etymologically) or historically (settling-wise) associated with the presence of the Vlach shepherds in these areas, it can be concluded that this region was not as densely populated by the Vlachs as the Bieszczady or even the more westerly Beskid Żywiecki and Beskid Śląski. Moreover, the names of rivers, villages and towns, as well as mountain ranges and summits in the Podtatrze region are not that phonetically or semantically close, and not as diverse as the toponyms registered in the areas of the Bieszczady and the East Beskids. In the Podkarpacie region, villages established under the Vlach law include Mików, see mic meaning small in Romanian (the Sanok District); Dziurdziów, see the Romanian name Giurgiu (the Krosno District); and Dragonowa, see the Romanian name Dragan (the Bieszczady District). However, traces of the Vlach shepherds' presence can be found both in the Podtatrze region as well as the Tatras themselves. They are ob-

${ }^{1}$ See E. Długopolski, Przywileje sołtysów podhalańskich, „Rocznik Podhalański” 19141921, 1, pp. 4-6.

2 S. Hrabec, Nazwy geograficzne Huculszczyzny, Kraków 1950, p. 122. 
viously evident in the dialects of the Podhale region and include mainly pastoral terminology such as: the Polish term bryndza (a fermented ground sheep milk cheese mixed with salt; ubiquitous across the entire Carpathian region) and the Romanian term brânză (any kind of cheese from any type of milk, except yellow cheese); the Polish dialectal term redykać (to put out sheep to seasonal pasture), see the Romanian verb a ridica (the archaic form of a rădica) meaning "to move, to go up"; the Polish term koszar, dial. kosar (a board-fenced room in an animal barn; a portable pen for sheep and other animals) the same meaning in Romanian. In comparison with the Romanian definitions, which were most commonly used in everyday language and not necessarily in dialects, in many cases the Polish meaning has been clearly narrowed. Over time, most of the vocabulary related to the terrain, such as the Romanian appellatives măgură (deal mare; izolat), (dial.) grun (movilă; colină), or chiceră (vârf; culme) have become proper names for numerous topographic points in the mountains, also in the High Tatras and Podtatrze region: Gronik - a large wooded hill constituting the end of the south-west Krywan ridge (Slovakia), a housing estate in Kościelisko, a mountain ridge and a housing estate in Zakopane; the Orava Magura, the Spiš Magura, and the Witowska Magura; Mt. Kiczora in the Belianske Tatras; and Grapa, which is a common term in the Podhale nomenclature: Mt. Galicowa Grapa and Mt. Klusiowa Grapa ${ }^{3}$. However, the above words existed much earlier as appellatives in the Podhale and Orava dialects, e.g. Groń or gróń (the Podhale dialect: a high riverbank or a ridge between two streams; the Orava dialect: a hill or a wooded slope), variants: gronik, zagroń; probably derives from the Romanian dialect term grui or the dialect term grúnu (movilă, colină) (rarely); there are two hypotheses on the origin of this word. Hypothesis 1: from the Thracian *goroneum, where the root ${ }^{*}$ gor- displays the relationship with the Proto-Slavic *gora, see the Indo-European ${ }^{*} g^{u}$ er- (mountain, forest); hypothesis 2: the Latin term grumus (movilă) <* grumeus < Romanian grui ${ }^{4}$. Grapa (a steep, rugged mountainside; a slope), variant: drapa; probably from the Romanian word groapă (mormânt, şanț) $)^{5}$, see the Albanian gropë (id.), the ProtoSlavic * grobr (a hole or a pit), and the Calabrian grupa (a hole) ${ }^{6}$.

${ }^{3}$ See: R. Mrózek, Nazwy górskie in: Polskie nazwy własne, ed. E. Rzetelska-Feleszko, Warszawa-Kraków 1998; A. Oczko, Rumuńskie echo w polskich górach - nazwy szczytów i gór pochodzenia rumuńskiego in: Polsko-rumuńskie zwiazki historyczne $i$ kulturowe. Legături istorice şi culturale polono-române, eds. St. Iachimovschi, E. Wieruszewska-Calistru, Suceava 2013, pp. 354-359.

${ }^{4}$ A. Ciorănescu, Dicţionarul etimologic al limbii române, Bucureşti 2002, p. 381.

${ }^{5}$ F. Sławski, Słownik etymologiczny języka polskiego, Kraków 1952, p. 341.

${ }^{6}$ P. Skok, Etimologijski Rječnik hrvatskoga ili srpskoga jezika, vol. 3, Zagreb 1973, p. 172. 
The Polish Podtatrze region includes three historical and geographical lands: Spiš - around the eastern slopes of the Tatras - and Orava from the west, both partly covering the Polish and Slovakian territories, and the biggest one: the Podhale region, which is located entirely in Poland, in the Dunajec basin, between the Tatras, the Podhale range, and Gorce. In the Polish Podtatrze region, there are currently 94 villages, 65 of which lie in Podhale, 14 in Spiš and 15 in Orava (in the Polish parts of these regions). In fact, traces of the Romanian dialect which was certainly spoken by the Vlach shepherds can be found only in a few oikonyms. What is surprising is the fact that not every village, which name can be linked with the Vlach origin (or the Romanian language) was established under the Vlach law. In many cases, however, there are preserved documents, which indicate that these villages were inhabited by the Vlachs.

In the Spiš region such villages include: Łapsze near Nowy Targ; the etymology of the name displays the Vlach and Romanian influences mentioned in Stownik etymologiczny miast i miejsc $P R L^{7}$ [The Etymological Dictionary of the Cities and Places of the PRL] and quoted therein after Łukasik $^{8}$, see the Romanian term lăpuş (a cuckoo flower).

Rzepiska - a village founded under the Vlach law in the first half of the $17^{\text {th }}$ century. The aforementioned Etymological Dictionary and other sources indicate the etymological relationship with the Albanian and Vlach [sic!] term repire, which seems unlikely, as such a form has not been recorded in the Romanian language. A more likely hypothesis is that the village name stems from the etymon repeziş (a steep bank of rapid water) or, according to my research, the Romanian term râpă (a steep, rugged mountainside) + the suffix -isko. Therefore, the etymology proposed by Władysław Lubaś must also be questioned, since he derives the name Rzepiska from the Polish word rzepisko (a place where potatoes grew) ${ }^{9}$.

In addition to the above-mentioned village, there are two more Spiš villages that were established under the Vlach law: Czarna Góra in 1589 - legend has it that the Vlach settlers came to the village from the Balkan Čarnohora. The third village is Jurgów (founded in 1546) on the Polish and Slovakian border.

In the Podhale region, there are currently only three villages whose name could be associated with the language of the Vlach shepherds:

\footnotetext{
${ }^{7}$ S. Rospond, Stownik etymologiczny miast i gmin PRL, Wrocław 1984, p. 258.

${ }^{8}$ S. Łukasik, Pologne et Roumanie. Aux confins des deux peuples et des deux langues, Paris 1938, pp. 287-288.

${ }^{9}$ W. Lubaś, Nazwy miejscowe południowej części dawnego województwa krakowskiego, Wrocław 1968, p. 132.
} 
Murzasichle - this name is a combination of the following elements: the Polish dialect term mur (steep rock walls or a high river bank) or, as other theories suggest, pomór (death), which seems unlikely, and the Romanian dialect term sihlă; see the Romanian word sihlă (a thicket; young woodland). The village is situated in the southern part of the Skalne Podhale region. In the Podhale dialect, sichta (sichla) means 'a boggy forest or a marsh area; a mountain bog' ${ }^{10}$. Indeed, Murzasichle is separated from the village of Poronin by the Porońca Valley. The village of Murzasichle was founded after World War II and was the merger of two housing estates - Mur and Zasichle, which traditionally had the same mayor.

Poronin - the name derives from the Poroniec River, by which a settlement was established as early as the $16^{\text {th }}$ century, although the Porońca Valley was mentioned in documents much earlier - in the mid- $13^{\text {th }}$ century. The name of the river Poroniec is linked with the Romanian word părâu, plural păroaie (a mountain stream) ${ }^{11}$.

Dzianisz - geographical and historical sources also associate this name with the language of the Vlach shepherds. Łukasik emphasizes the analogy with the Aromanian term dzeana, plural dzenuri (sourcil, colline) ${ }^{12}$. Other etymologies which refer the name to the word stream are rather unconvincing, see dziać się (to carve, to furrow) ${ }^{13}$. In my opinion, the name of the village might stem from the Romanian geană, which major meaning is "eyelash"; however, in the Moldovan dialects - geană dealului means the highest part of the hill, including the peak - which is highly probable ${ }^{14}$ since Dzianisz is situated much higher than Chochołów and Witów, with its highest part reaching the peak of Mt. Butorowy Wierch. The suffix -niş, iş, also of Romanian origin, forms the names of places, by analogy to the Romanian poiana - dialectal poieniş.

In the Podtatrze travel guide, Maciej Pinkwart ${ }^{15}$ states that the two oldest districts of Zakopane - Olcza and Ustup, once separate villages, were founded under the Vlach law in the early $17^{\text {th }}$ century (although the first settlers arrived there at the turn of the $15^{\text {th }}$ and $16^{\text {th }}$ centuries). In addition, old maps tend to distort the term Olczysko (a folk form of the names: Olczyska Valley, Polana Olczyska, and Hala Olczyska, where Olcza residents had their pastures) into Wolczisko or Wołczysko $0^{16}$ - whether or not

\footnotetext{
${ }^{10}$ Ibidem, p. 98.

${ }^{11}$ S. Łukasik, op. cit., p. 272.

${ }^{12}$ Ibidem, p. 264.

${ }^{13}$ W. Lubaś, op. cit., p. 45.

${ }^{14}$ D. Moldovanu, Teoria câmpurilor toponimice, Iaşi 2010, p. 162.

${ }^{15}$ M. Pinkwart, Podtatrze, Olszanica 2011.

${ }^{16}$ Z. and W. Paryscy, Wielka encyklopedia tatrzańska, Poronin 1995, p. 841.
} 
these names are related to the Vlach settlement is now only a far-reaching hypothesis, which would require a detailed study of old documents and maps, especially the ones compiled during the Austro-Hungarian period.

In the Orava region, there is one village, which name could derive from the language of the Vlach shepherds or the Romanian language - Kiczory, mentioned in 1638 as a district of Lipnica Wielka, today an individual village. The Romanian chiceră means 'a summit', the same term exists in Albanian qiqë(lë). The Polish mountain dialects register many different variants of that Romanian word as Kiczera, Kiciurka, Kiciura (wooded mountain). However, in comparison with other areas of the Polish Podtatrze region, it is Orava where people settled under the Vlach law most often. These are the villages of: Jabłonka, established in 1558 (unfortunately, documents were lost), Piekielnik (est. 1606), and Lipnica Wielka (est. 1606). Moreover, in the case of the village of Lipnica Mała, the documents dated from 1618 confirm that there were five Vlach settlers in the village (in the Orava dialect: siedlak means "a peasant" ${ }^{17}$, and it is known that Vlach settlers also lived in Podwilk.

The Vlach shepherds started settling in the Podtatrze region from the mid- $16^{\text {th }}$ century - however, choosing a new place to live was not always synonymous with founding a new settlement. As examples may serve the village of Podwilk, the Orava region (the name of this villages derives from a surname of its first village leader, who was called Feliks Wilczek) or the village of Jabłonka, which was mentioned in written sources already in the $14^{\text {th }}$ century. Acquiring settlement rights based on ius valahicum was not always equivalent to giving the village a name deriving from the foreign Vlach speech. As typically Polish oikonyms, confirming the above mentioned rule, we should treat names such as: Jabłonka, whose etymology is rooted in local dialects and refers to the Polish word signifying an apple tree (jabłon); Czarna Góra - a name deriving from a hill covered with dark spruce forest, on which the village was located; Lipnica Wielka named after a stream Lipniczanka along which its households were built. As far as village names with roots in the language of the Vlach settlers are concerned, they also cannot be directly associated with the fact that they were established under the Vlach law. The majority of toponyms, which etymons originated in Romanian dialects, refer to specific features of the environment in which a village was founded, e.g. the already mentioned villages of Łapsze, Poronin or Dzianisz - those names refer either to characteristics of local flora or to features of landscape. In conclusion, it was mostly the popularity of the language of the Vlach shepherds, resulting

${ }^{17}$ J. Kąś, Słownik gwary orawskiej, Kraków 2011, p. 311. 
in widespread borrowings into dialects of local highlanders (which can be also analysed in context of a wider phenomenon of the Carpathian linguistic community), which was reflected in local onomastics. On the other hand, it must be stated that the process of village location in the Podtatrze region upon ius valahicum, i.e. based on political and administrative decisions, did not have a deeper correlation with names of newly-founded settlements.

Finally, it is important to add a few remarks concerning methodology. When studying the toponymy of villages established and based on Vlach law, and also those inhabited by Vlach settlers, one should also take into consideration the names of housing estates and hamlets which are usually disregarded in general toponymic and etymological studies. Furthermore, it is necessary to analyze older documents and maps, e.g. from the period of the Austro-Hungarian Empire, where individual toponyms may be written down in a different way than today, e.g. Olczysko - Wołczysko. Therefore, this article does not exhaust the issue of the toponymy of the Polish Podtatrze region and it should be treated solely as an introduction to more extensive studies, which ought to be undertaken in the context of the Vlach presence on the Polish territory, especially since current publications do not address all issues related to this phenomenon.

\section{BIBLIOGRAPHY}

Ciorănescu A., Dicționarul etimologic al limbii române, Bucureşti 2002 (DER).

Długopolski E., Przywileje sołtysów podhalańskich, „Rocznik Podhalański” 1914-1921, 1.

Hrabec S., Nazwy geograficzne Huculszczyzny, Kraków 1950.

Kąś J., Stownik gwary orawskiej, Kraków 2011.

Lubaś W., Nazwy miejscowe południowej części dawnego województwa krakowskiego, Wrocław 1968.

Łukasik S., Pologne et Roumanie. Aux confins des deux peuples et des deux langues, Paris 1938.

Moldovanu D., Teoria câmpurilor toponimice, Iaşi 2010.

Mrózek R., Nazwy górskie in: Polskie nazwy własne, ed. E. Rzetelska-Feleszko, WarszawaKraków 1998.

Oczko A., Rumuńskie echo w polskich górach - nazwy szczytów i gór pochodzenia rumuńskiego, in: Polsko-rumuńskie zwiazki historyczne i kulturowe. Legături istorice şi culturale polonoromâne, eds. St. Iachimovschi, E. Wieruszewska-Calistru, Suceava 2013.

Paryscy Z. and W., Wielka encyklopedia tatrzańska, Poronin 1995.

Pinkwart M., Podtatrze, Olszanica 2011.

Rospond S., Stownik etymologiczny miast i gmin PRL, Wrocław 1984.

Skok P., Etimologijski Rječnik hrvatskoga ili srpskoga jezika, Zagreb 1971.

Sławski F., Słownik etymologiczny języka polskiego, Kraków 1952-1986. 


\section{ABSTRACT}

In the Podhale dialects there are lexical items, the origin of which is associated with the migration of Vlach shepherds across the Polish Podtatrze region. They are also present in toponymy. They are usually formed and based on the Romanian dialect appellatives, e.g. the oronyms Grapa and Magura or the names of villages established under the Vlach law or inhabited by Vlach settlers, e.g. Eapsze and Poronin. Out of 93 villages in the Polish Podtatrze region, covering Spiš, Podhale, and Orava, only five cases display the clearly observable Romanian (Vlach) etymology - at least according to existing research. However, this is not the ultimate state of research as the topic requires further investigation.

Key words: Vlachs, the Tatras, toponymy of Podhale, Vlach settlements

\section{ABOUT AUTHOR}

Anna Oczko - a linguist at the Department of Romanian Studies, Institute of Romance Philology of the Jagiellonian University. Her academic interests include diachronic linguistics focused on the area of Romanian language and more recently also toponomastics. In addition to other works, she authored a monograph Rumuńska Słowiańszczyzna. Zapożyczenia południowosłowiańskie w języku rumuńskim w XVI i XVII wieku, published in 2014. 